DOI https://doi.org/10.30525/978-9934-26-000-1-17

\title{
УКРАЇНСЬКА МОВА В СУЧАСНОМУ МЕДІАПРОСТОРІ
}

\author{
Бондарчук К. С. \\ доцент кафедри украӥнознавства та загальної мовної підготовки \\ Національний університет «Запорізька політехніка» \\ м. Запоріжжя, Украӥна
}

Велику роль у громадському житті країни відіграють засоби масової інформації, які активно реагують на суспільно-політичні процеси й віддзеркалюють ї. Здатність швидко охоплювати найширші аудиторії дає їм змогу формувати суспільну думку, визначати духовні цінності, впливати на громадську свідомість. Тому надзвичайно важливим $\epsilon$ питання мовної культури українського медіапростору, адже мова $\epsilon$ найважливішим засобом людського спілкування та інтелектуального розвитку особистості, визначальною ознакою державності, безцінною і невичерпною скарбницею культурного надбання народу. 3MI, зокрема телебачення і радіо, на сьогодні є найдоступнішим джерелом отримання різних видів інформації для широкого загалу населення України. Тому для працівників мас-медіа $\epsilon$ актуальним високий рівень володіння літературними нормами сучасної української мови на всіх іiі рівнях і, відповідно, пильніше дбати про іiї чистоту та збереження багатовікових надбань, не втрачати питомі корені іiі джерел. Особливу увагу привертає мовлення телеведучих, адже завдяки розмаїттю мовних засобів вони не лише інформують, а і впливають на формування комунікативних навичок, словниковий запас глядачів і слухачів. Через великий вплив ЗМІ важливим $є$ питання про те, якою мовою вони інформують. Згідно з законом «Про телебачення та радіомовлення», частка української мови на загальнонаціональних каналах має становити 75\%, що переважно дотримується, а це сприяє прагненню користувачів до оволодіння державною мовою.

Останніми роками медійний простір України перенасичений різноманітними шоу, круглими столами, презентаціями програм, проєктів як державного, так і місцевого рівня. Українці мають можливість чути публічних людей - державних діячів, керівників та провідних фахівців різних сфер життєдіяльності, політологів, мовлення яких і стало предметом наших досліджень. Слід зауважити, що рівень комунікативних умінь учасників таких масових дебатів не завжди високий, що визначає актуальність наших спостережень. Питання мовної культури були предметом лінгвістичних досліджень мовознавців, які розглядали мову як систему (В. Виноградов, І. Огієнко, О. Потебня), а також у практичному аспекті, тобто культуру мовлення фахівців різного профілю, дер- 
жавних службовців (Н. Бабич, М. Мельник, I. Плотницька, Т. Русак та інші). Мова сучасних українських засобів масової інформації $є$ також багатим джерелом для вивчення новітніх тенденцій у розвитку сучасної літературної мови, активного поповнення їі новою лексикою. Зокрема, функціювання неологізмів у мас-медіа описано в працях К. Городенської, Є. Карпілової, Ж. Колоїз, Н. Клименко, Л. Кислюк [1; 2]

Мета нашої роботи - дослідити рівень культури усної комунікації публічних людей, виявлений під час виступів у телевізійному просторі.

Проблеми використання неологізмів у ЗМІ тісно пов'язані 3 питаннями культури мовлення, адже вони сприяють перетворенню нових слів у одиниці загальновживаного словника.

На нашу думку, медійний простір перевантажений далеко не завжди виправданим уживанням іншомовних лексем на кшталт кайф, меседж, піар (PR), о’кей, тренд, хайк, пранкер тощо. Переважна більшість таких слів мають українські відповідники, зрозумілі широкому загалові: електорат (виборці), кастинг (відбір), шоу (видовище), консенсус (згода), ультиматум (вимога), о'кей (гаразд, добре, чудово, так, зрозуміло) тощо. Серед неологізмів мають місце синоніми, що поновому передають ставлення мовця до вже відомих понять, явищ, предметів, виділяючи в них своєрідну, досі не відому чи не помічену особливість, рису, грань. До них належать, зокрема, такі слова, як бутік (невелика крамниця 3 модними дорогими товарами); людомор, поморівок (штучно створений голод; голодомор) тощо. На наш погляд, слова людомор, поморівок досить вдалі, з яскраво вираженою семантикою та суб'єктивною оцінкою цього явища. А слово бутік порушує словотвірні норми української мови, адже суфікс -iк не характерний для неї.

Серед нових слів, що активно поповнюють лексико-семантичну систему мови, помітне місце посідають словотвірні неологізми, для творення яких залучені іншомовні та українські складники: поліmбомонд, працетерапія, снідоносний, червонохрестівецьь (співробітник Товариства Червоного Хреста). Найбільш продуктивним морфологічним способом творення неолексем $\epsilon$ префіксально-суфіксальний (десоветизаичія, декомунізація, постсовковий, пострадянський, посткомуністичний, антиринковий, антиінфляційний, супермодерновий). Велика кількість таких слів, що активно вживаються в мас-медіа, номінує явища, пов'язані 3 радянською добою і мають оцінювальні негативні конотації. Часто неологізми творяться за допомогою суфіксів (відосик, піарник, піарівський, мажоритарник, опозиційник, спікерство, гуманітарка, мобілка, марирутка), причому твірною основою часто виступають абревіатури: натовецьь (НАТО), есбеушник (СБУ), емеефівський (МВФ). Продуктивними для творення нових слів $є$ також префікси, переважна частина яких іншомовного походження: квазіеліта, квазіпатріот, псевдоринок, псевдодемократія, суперакція, ультранаціоналіст тощо. Такі неологізми видаються цілком вдалими, не порушу- 
ють норми українського словотвору. Доволі активно використовуються в ЗМІ індивідуально-авторські неологізми, або оказіоналізми: елітовихований, серцеекий, святотворення, що несуть у собі як позитивну, так і негативно марковану оцінку: інтербезбатченко, манкуртопарламенmар, нац'євнух тощо. У ЗМІ широко функціює неологічна запозичена лексика зі сфери електронних засобів зв'язку, на базі якої утворюються похідні лексеми: боти, порохоботи; лайки, лайкнути; хіт, хітпарад, хітова (пісня, програма); фейк, фейкові новини. Слід зазначити, що невиправдано продукуються неологізми-жаргонізми, які засмічують українську мову, знижують тональність спілкування: засвітитися (проявити себе); загнутися (зазнати поразки); зависнути на чомусь (звернути увагу); наварювати (одержувати прибутки); прикид (одяг); бабки (гроші); прикол (щось особливе), заиквар (ганебне явище), лох (простак) та ін.

У мовленні медійників та їх гостей часто порушуються літературні мовні норми, що зазвичай $є$ результатом взаємодії української та російської мов, тому аналіз помилок, на наш погляд, сприятиме їх усвідомленню мовцями, розумінню необхідності оволодіння нормами сучасної української мови. Найбільш поширені порушення літературних норм на різних мовних рівнях учасниками усних публічних презентацій виявлені такі.

Орфоепічні помилки, пов'язані 3 неправильною вимовою, як-от: проблєма замість проблема; срок замість строк; вимова м'яких шиплячих звуків замість твердих (ще, хоче,чому, щоб, частина); вимова ж замість дж (хожу, нагорожений), вимова звуків з російським акцентом (акання, цекання, оглушення дзвінких приголосних у кінці слова та складу).

Акцентуаційні помилки (неправильне наголошування слів): випадок замість випадок, говорю замість говорю, кілька років тому замість тому, такий самий замість самий, судове рішення замість судове, фахова людина замість фахова.

Лексичні помилки: тавтологія (керівники покращують керівницчтво), русизми (повисити рівень замість підвищити; матеріальне обеспечення замість забезпечення; даний момент замість цей; виключення замість виняток; сьогодня замість сьогодні; вот замість ось); словапаразити (та? у значенні так?); нерозуміння лексичного значення слова (перебрали досвід замість врахували; не дивлячись на обставини замість незважаючи; відсутній у законі замість немає або бракує в законі; немає змісту замість сенсу; кар'єрний ріст замість кар'єрне зростання); перефразування російських фразеологізмів (під відкритим небом замість просто неба) або деформування українських (пани сваряться - у кріпаків лоби тріщать замість пани чубляться кріпаків чуби тріщцать). 
Морфологічні: уживання не властивих українській мові активних дієприкметників (відволікаючий момент; замість момент, щуо відволікає; командуючий військами замість командувач військ; завідуючий сектором замість завідувач сектору); порушення норм ступенювання прикметників (найбільш сприятливіший замість найбільш сприятливий; самий відчутний замість найвідчутніший); відмінювання кількісних числівників (трьохста п'ятидесяти справ замість трьохсот n'ятдесяти; шістьюстами, шестистами замість шістьмастами); поєднання числівників з іменниками (три депутата замість депутати, два лікаря замість лікарі); порушення норм словотвору (Венеціанська комісія замість Венеційська, канадійці замість канадиі) тощо.

Отже, мова сучасних українських засобів масової інформації є живим організмом, вона еволюціонує, наповнюється новими лексемами, серед яких можна виокремити як позитивний доробок, так і ті новотвори, що не завжди відповідають чинним нормам української мови, часто засмічують іiі, заповнюючи медійний простір просторічною, жаргонною, інколи неетичною лексикою. Рівень культури мовлення представників 3МІ та публічних людей у телевізійному просторі можна визначити як не цілком високий. Серед найбільш поширених порушень норм літературної української мови є неправильна вимова звуків, наголошування слів, уживання мовних кальок з російської мови, що виявляється переважно на лексичному та морфологічному рівнях, перенасичення не завжди виправданими запозиченнями, зокрема неологізмами.

\section{Література:}

1. Динамічні процеси в сучасному українському лексиконі/ Н. Ф. Клименко, Є.А. Карпілова, Л.П. Кислюк - К. : Видавн. Дім Д. Бураго, 2008. - 336 с.

2. Колоїз Ж. В. До питання про диференціацію основних понять неології. Вісник Запорізького ун-ту: Філологічні науки. -Запоріжжя, 2002. - № 3. - C. 78-83. 